\title{
Analysis of Stored Wheat Grain-Associated Microbiota Reveals Biocontrol Activity among Microorganisms against Mycotoxigenic Fungi
}

\author{
Manoj Kumar Solanki ${ }^{1,+, \pm(\mathbb{D}, \text { Ahmed Abdelfattah }}{ }^{2,+}{ }^{\circledR}$, Sudharsan Sadhasivam ${ }^{1}\left(\mathbb{D}\right.$, Varda Zakin ${ }^{1}$, \\ Michael Wisniewski ${ }^{3}$, Samir Droby ${ }^{1, *}$ and Edward Sionov ${ }^{1, * \mathbb{D}}$ \\ 1 Volcani Center, Agricultural Research Organization, Institute of Postharvest and Food Sciences, \\ Rishon LeZion 7528809, Israel; mkswings321@gmail.com (M.K.S.); sudharsan@volcani.agri.gov.il (S.S.); \\ veredz@volcani.agri.gov.il (V.Z.) \\ 2 Institute of Environmental Biotechnology, Graz University of Technology, Petersgasse 12, \\ A-8010 Graz, Austria; ahmed.abdelfattaah@gmail.com \\ 3 Agricultural Research Service, United States Department of Agriculture (USDA-ARS), 2217 Wiltshire Road, \\ Kearneysville, WV 25430, USA; Michael.Wisniewski@ars.usda.gov \\ * Correspondence: samird@volcani.agri.gov.il (S.D.); edwardsio@volcani.agri.gov.il (E.S.) \\ $+\quad$ These authors contributed equally to this work. \\ $\ddagger$ Current address: Plant Cytogenetics and Molecular Biology Group, Faculty of Natural Sciences, Institute of \\ Biology, Biotechnology and Environmental Protection, University of Silesia in Katowice, \\ 40-032 Katowice, Poland.
}

check for updates

Citation: Solanki, M.K.; Abdelfattah, A.; Sadhasivam, S.; Zakin, V.; Wisniewski, M.; Droby, S.; Sionov, E. Analysis of Stored Wheat

Grain-Associated Microbiota Reveals Biocontrol Activity among Microorganisms against Mycotoxigenic Fungi. J. Fungi 2021, 7 , 781. https://doi.org/10.3390/ jof7090781

Academic Editor: Kimiko Yabe

Received: 26 August 2021

Accepted: 17 September 2021

Published: 20 September 2021

Publisher's Note: MDPI stays neutral with regard to jurisdictional claims in published maps and institutional affiliations.

Copyright: (c) 2021 by the authors. Licensee MDPI, Basel, Switzerland. This article is an open access article distributed under the terms and conditions of the Creative Commons Attribution (CC BY) license (https:// creativecommons.org/licenses/by/ $4.0 /)$.
Abstract: Wheat grains are colonized by complex microbial communities that have the potential to affect seed quality and susceptibility to disease. Some of the beneficial microbes in these communities have been shown to protect plants against pathogens through antagonism. We evaluated the role of the microbiome in seed health: in particular, against mycotoxin-producing fungi. Amplicon sequencing was used to characterize the seed microbiome and determine if epiphytes and endophytes differ in their fungal and bacterial diversity and community composition. We then isolated culturable fungal and bacterial species and evaluated their antagonistic activity against mycotoxigenic fungi. The most prevalent taxa were found to be shared between the epiphytic and endophytic microbiota of stored wheat seeds. Among the isolated bacteria, Bacillus strains exhibited strong antagonistic properties against fungal pathogens with noteworthy fungal load reduction in wheat grain samples of up to a $3.59 \log _{10} \mathrm{CFU} / \mathrm{g}$ compared to untreated controls. We also found that a strain of the yeast, Rhodotorula glutinis, isolated from wheat grains, degrades and/or metabolizes aflatoxin $\mathrm{B}_{1}$, one of the most dangerous mycotoxins that negatively affects physiological processes in animals and humans. The mycotoxin level in grain samples was significantly reduced up to $65 \%$ in the presence of the yeast strain, compared to the untreated control. Our study demonstrates that stored wheat grains are a rich source of bacterial and yeast antagonists with strong inhibitory and biodegradation potential against mycotoxigenic fungi and the mycotoxins they produce, respectively. Utilization of these antagonistic microorganisms may help reduce fungal and mycotoxin contamination, and potentially replace traditionally used synthetic chemicals.

Keywords: biocontrol; stored wheat grain microbiota; epiphytes; endophytes; mycotoxigenic fungi; mycotoxins

\section{Introduction}

Wheat is one of the major cultivated grain crops, and an important source of calories and plant-derived protein in the human diet. The maintenance of high-quality and healthy wheat grains is essential to ensuring the stability of the world's food supply and providing global food security. Wheat grains, like seeds of other cereal crops, are colonized by complex epiphytic and endophytic microbial communities that play an important role in 
grain health, quality, and susceptibility to disease [1]. Microorganisms, both bacteria and fungi, naturally occur in cereal crops without causing any damage, and may influence host growth and development. Conversely, other microorganisms can cause disease and spoilage, thereby decreasing crop value, and may also have a harmful effect on human health. For example, many species of Fusarium, Aspergillus, Penicillium, and Alternaria are not only recognized as plant pathogens but also as sources of important mycotoxins of concern to animal and human health [2,3]. Poor postharvest management can lead to rapid deterioration in grain quality, with severe decreases in germinability and nutritional value of the stored grain, possibly accompanied by undesirable fungal contamination and, consequently, toxin production [4]. Mycotoxigenic fungal species may also cause significant wheat grain yield losses in field and storage facilities due to their ability to produce mycotoxins and render the crops unsafe for consumption [5-9]. Despite the major threat posed by these fungi, effective control measures are lacking. Current diseasemanagement practices are primarily based on the use of synthetic fungicides, which have proven to be effective against several genera of mycotoxigenic fungi, applying them in the field before harvest. Increasing awareness of the possible harmful effects of these chemical compounds on the environment and human health, however, has fostered research to find effective and less toxic alternative strategies to control fungal infections.

Biological control using microbial antagonists against fungal plant pathogens is one alternative approach that can be used as part of an integrated management strategy for the control of mycotoxigenic fungi and mycotoxin contamination in stored wheat. The protective ability of some bacterial epiphytes and endophytes against fungal pathogens has been reported in several crops, including wheat [1,10-13]. Nevertheless, one of the major drawbacks associated with the use of biological control agents is their inconsistent efficacy over time [14,15]. This can be attributed in part to the fact that most commercially available biocontrol isolates do not originate from the plants that they are intended to protect, a factor that may be related to their inconsistent performance in the field and/or storage warehouses. Exploring the epiphytic and endophytic composition of the stored wheat grain microbiome may help in identifying novel antagonistic microorganisms with potential antifungal and antitoxigenic activity. The major objective of the present study was to use amplicon sequencing to identify and characterize the epiphytic and endophytic microbiome of stored wheat grain. We then examined the potential of the culturable microorganisms isolated from stored seeds to inhibit the growth of mycotoxigenic fungi and degrade their toxins.

\section{Materials and Methods}

\subsection{Wheat Grain Sources}

Twenty-seven samples of wheat grain (Triticum aestivum) were collected from three wheat grain storage facilities located in northern and southern districts of Israel. In each of the three storage facilities, nine samples ( $1 \mathrm{~kg}$ of grain each), destined for human consumption, were collected in equal proportions $(9$ samples $\times 3$ storage sites $=$ a total of 27 samples) from the front face and center, at points located at $1 \mathrm{~m}$ horizontal depth within the grain mass, and from areas close to the walls. Grain temperature and moisture content were in the ranges of $27-33^{\circ} \mathrm{C}$ and $10.5-12.9 \%$, respectively. The collected samples were kept in sterile plastic bags during transport to the laboratory and stored at $4{ }^{\circ} \mathrm{C}$ (for up to 4 weeks) for further analysis.

\subsection{DNA Extraction, Amplification, and Sequencing}

To isolate DNA from epiphytic microbiota, $10 \mathrm{~g}$ of each grain sample was soaked in $45 \mathrm{~mL}$ peptone water ( $10 \mathrm{~g} / \mathrm{L}$ peptone, $5 \mathrm{~g} / \mathrm{L} \mathrm{NaCl}$ ) (Difco; Becton Dickinson, Franklin Lakes, NJ, USA) containing 0.05\% Triton X-100 (Sigma, Saint Louis, MO, USA) in a 250-mL Erlenmeyer flask and shaken at room temperature on an orbital shaker at $150 \mathrm{rpm}$ for $1 \mathrm{~h}$. Grains were aseptically removed by filtration through 4 layers of sterile cheesecloth and the remaining liquid fractions were centrifuged at $4000 \times g$ for $15 \mathrm{~min}$. Pellets were collected 
and immediately frozen in liquid nitrogen, freeze-dried, then subjected to DNA extraction. DNA from endophytic microbiota was isolated after surface sterilization of wheat grains with 3\% sodium hypochlorite for $2 \mathrm{~min}$, followed by $70 \%$ ethanol for $2 \mathrm{~min}$ and rinsing five times in sterile distilled water. Surface-sterilized wheat grains $(10 \mathrm{~g})$ were frozen in liquid nitrogen, freeze-dried and milled into a fine powder with a grain grinder. The grain grinder was cleaned and disinfected with $70 \%$ ethanol solution between samples and the powder was used for DNA isolation. Extraction of both epiphytic and endophytic DNA samples was performed using a previously described protocol [16]. The purity of the extracted DNA was assayed with a Nanodrop ${ }^{\mathrm{TM}}$ One spectrophotometer (Thermo Scientific, Wilmington, DE, USA), and the total DNA concentration in each sample was adjusted to $50 \mathrm{ng} / \mu \mathrm{l}$. The universal primers $799 \mathrm{~F} / 1392 \mathrm{R}$ [17] and 5F/86R [18] were used to amplify the $16 \mathrm{~S}$ and ITS2 rRNA gene regions of bacteria and fungi, respectively (Supplementary Materials Table S1). The primers were modified to include Illumina adapters (www.illumina.com (accessed on 7 March 2019)) for subsequent multiplexing. PCR amplification of each sample was performed in triplicate. The PCR mixture $(25 \mu \mathrm{L})$ contained $12.5 \mu \mathrm{L} 2 \times$ DreamTaq Green PCR Master Mix (Thermo Scientific, Vilnius, Lithuania), $1 \mu \mathrm{L}$ of each primer $(5 \mu \mathrm{M})$, and 1 $\mu L$ DNA template. Nuclease-free water (Thermo Scientific) replaced the DNA template in negative controls. All amplicons and amplification mixtures, including negative controls, were sequenced using Illumina MiSeq V3 $(2 \times 300 \mathrm{bp})$ chemistry.

\subsection{Bioinformatics}

Illumina adaptors were clipped and low-quality reads removed by Trimmomatic 0.36 [19] using sliding-window trimming, cutting once the average quality in a window of 4 bases fell below the quality threshold of 15 . Paired-end reads were merged utilizing PEAR [20] for the 16S rRNA gene, and PANDAseq [21] for the ITS rRNA gene region sequences with default parameters. Chimeric sequences were identified and removed using USEARCH [22,23] for the 16S rRNA gene, and VSEARCH 1.4.0 [24] for ITS rRNA gene region sequences. UCLUST algorithm [22], as implemented in QIIME 1.9.1 [25], was used to cluster sequences queried against the Greengenes 13_8_97 database for 16S rRNA genes [26], and for ITS UNITE dynamic database released on 1 December 2017 [27] at a similarity threshold of $97 \%$, respectively. Sequences that failed to cluster against the database were de novo clustered using the same algorithm. After removing singletons, the most abundant sequences in each operational taxonomic unit (OTU) were selected as representative sequences and used for the taxonomic assignment with the BLAST algorithm [23,28] as implemented in QIIME 1.9.1. The OTU table was normalized by rarefaction to an even sequencing depth in order to eliminate sample heterogeneity. The OTU tables were rarefied to 300 bacterial and 8000 fungal sequences per sample and used to calculate $\alpha$-diversity indices, including observed species $\left(\mathrm{S}_{\mathrm{obs}}\right)$ and Shannon index. The $\alpha$ diversities were compared based on a two-sample t-test using nonparametric (Monte Carlo) methods and 999 Monte Carlo permutations. Results were visualized in boxplot figures.

MetagenomeSeq's Cumulative Sum Scaling (CSS) [29] was used as a normalization method for other downstream analyses. The CSS-normalized OTU table was analyzed using Bray-Curtis metrics [30] and utilized to evaluate $\beta$-diversity and construct principal coordinates analysis (PCoA) plots using Emperor [31]. The similarity in community composition was tested via ANOSIM in QIIME 1.9.1 using 999 permutations. Differential OTU abundance of the most abundant taxa $(\geq 0.1 \%)$ between sample groups was determined by $t$-test and Kruskal-Wallis test [32]. In all tests, significance was determined using 999 Monte Carlo permutations; the false discovery rate (FDR) was used to adjust the calculated $p$-values and when the FDR $p<0.05$, it was considered significant (Tables S2 and S3).

\subsection{Isolation and Identification of Microorganisms}

To isolate epiphytic microorganisms from wheat grains, $10 \mathrm{~g}$ of whole grain samples were incubated in $45 \mathrm{~mL}$ of sterile peptone water (Difco; Becton Dickinson, Franklin Lakes, NJ, USA) and shaken (150 rpm) at room temperature for $1 \mathrm{~h}$. Then, $100-\mu \mathrm{L}$ aliquots of 
serial dilutions of the broth were plated on Luria-Bertani (LB) agar plates for isolation of bacteria, and potato dextrose agar (PDA) plates supplemented with chloramphenicol $(20 \mu \mathrm{g} / \mathrm{mL})$ for isolation of filamentous fungi and yeasts. To isolate endophytic microbes, $5 \mathrm{~g}$ of sterilized, ground wheat grain samples were added to $45 \mathrm{~mL}$ of sterile peptone water, and $100-\mu \mathrm{L}$ aliquots of serial dilutions were plated on LB agar plates for isolation of bacteria and PDA plates supplemented with chloramphenicol for isolation of filamentous fungi and yeasts. Inoculated LB agar plates were incubated at $37^{\circ} \mathrm{C}$ for $24-48 \mathrm{~h}$, whereas PDA plates were incubated at $28^{\circ} \mathrm{C}$ for $48-72 \mathrm{~h}$. Bacterial colonies were randomly selected from the plates and streaked on fresh culture media to obtain pure cultures. Filamentous fungi and yeasts were transferred singly to PDA plates and subcultured twice to obtain pure cultures. DNA was extracted from each bacterial strain using the lysozyme lysis method described by De et al. [33]. Fungal DNA extraction was performed on lyophilized mycelium/yeast cells using the CTAB-based method as previously described [16]. DNA quality and yield were determined using the Nanodrop One spectrophotometer. The 16S rRNA gene in bacteria, ITS rRNA gene region in fungi, and D1/D2 domain of large-subunit ribosomal DNA (rDNA) in yeast were amplified with universal primers 27F/1492R, ITS1/ITS4, and NL1/NL4, respectively (Table S1). PCR products were purified and sequenced by standard Sanger sequencing; sequences were identified via BLAST matches to the NCBI database (https:/ /blast.ncbi.nlm.nih.gov/Blast.cgi (accessed on 26 June 2021)) and deposited as accession numbers MZ452446-MZ452604 (bacterial 16S rRNA gene), MZ578164-MZ578238 (fungal ITS rRNA gene region) and MZ452263-MZ452328 (D1/D2 domain of large-subunit rDNA in yeast).

\subsection{In Vitro Antagonism against Mycotoxigenic Fungi}

Mycotoxigenic fungal isolates Aspergillus flavus (NRRL3518) and Fusarium proliferatum (NRRL31866) were obtained from USDA Agricultural Research Service Culture Collection (Northern Regional Research Laboratory, Peoria, IL, USA); Alternaria infectoria (strain F11) was isolated from stored wheat grains. Strains were refreshed from $-80^{\circ} \mathrm{C}$ by subculturing on PDA plates and maintained at $28^{\circ} \mathrm{C}$ before each experiment. Conidia were collected in sterile saline and the conidial suspension was adjusted to the required concentration by counting in a hemocytometer. The inoculum of the test strains was verified by plating on PDA plates for determination of colony forming units (CFU) counts. The possible antagonistic effects of the obtained bacterial and yeast isolates against the mycotoxigenic fungi were assessed by dual-culture method. Each bacterial/yeast strain and fungal isolate were inoculated on a 90-mm PDA plate. Each tested bacterium or yeast was precultured overnight in LB broth or potato dextrose broth (PDB), respectively, and streaked in a straight line in the center of the 90-mm Petri dish, then $5 \mu \mathrm{L}$ of fungal spore suspension at $10^{7}$ spores $/ \mathrm{mL}$ was spotted at opposite edges of the plate. The plates were sealed with parafilm and incubated at $28{ }^{\circ} \mathrm{C}$ until the mycelia in the untreated controls reached the center of the plates.

The production of volatile metabolites with antifungal activity released by bacterial and yeast isolates was also investigated. Precultivated overnight cultures of each bacterial or yeast strain were inoculated on a 55-mm LB or PDA agar plate, respectively, and incubated at $28^{\circ} \mathrm{C}$ for 3 days. Then, the lids of these plates were replaced by the bottom of a PDA plate inoculated with a fresh fungal mycelial plug. Plates were sealed together with sticky tape to minimize gas exchange and further incubated for 5 days. Controls were prepared in a similar manner, but the bottom plate contained no bacteria/yeast. In all of these experiments, growth inhibition $(\mathrm{mm})$ of the tested fungi was measured with a ruler and compared with the fungal growth in the untreated control plates. At least three independent repetitions of each test were conducted.

\subsection{Biocontrol Activity of Selected Bacterial Strains and Yeast against Mycotoxigenic Fungi on Wheat Grains}

Surface-disinfected seeds of wheat (10 g) were placed in sterile Petri dishes and inoculated with $1 \mathrm{~mL}$ of a cell suspension of overnight culture $\left(\mathrm{OD}_{600}=1.00\right)$ of each 
bacterial and yeast isolate selected based on their inhibitory effect on fungal growth. Grains treated with sterile saline instead of bacterial/yeast inoculum were used as negative controls. After $24 \mathrm{~h}$ incubation at $28^{\circ} \mathrm{C}$, wheat grains were inoculated with $1 \mathrm{~mL}$ of $10^{5}$ conidia/ $\mathrm{mL}$ of each fungal isolate. Untreated wheat grains were also inoculated with fungal conidia and served as positive controls. Plates were incubated at $28^{\circ} \mathrm{C}$ for 7 days and fungal development was assessed visually. For each bacterial and/or yeast treatment of wheat grains inoculated with each fungal isolate, at least three independent experiments were conducted. The antifungal activity of bacterial and/or yeast strains on inoculated wheat grains was evaluated using the plate counting method and expressed as fungal colony-forming units (CFUs)/g dry weight of wheat grains. Briefly, grain samples (5 g) were suspended in $50 \mathrm{~mL}$ phosphate-buffered saline containing $0.05 \%$ Triton X-100 and incubated with shaking $(160 \mathrm{rpm})$ at $28^{\circ} \mathrm{C}$ for $30 \mathrm{~min}$, then $100 \mu \mathrm{L}$ of serial dilutions of the suspension were plated on PDA plates supplemented with chloramphenicol, followed by incubation at $28^{\circ} \mathrm{C}$ for 4 days, for counting of fungal CFUs.

\subsection{Aflatoxin-Degradation Assays}

Commercial aflatoxin $\mathrm{B}_{1}\left(\mathrm{AFB}_{1}\right)$ standard was purchased from Fermentek (Jerusalem, Israel). $\mathrm{AFB}_{1}$ at a concentration of $1 \mathrm{mg} / \mathrm{mL}$ was dissolved in methanol and stored at $-20^{\circ} \mathrm{C}$. Based on previous reports indicating that the yeast Rhodotorula glutinis negatively affects mycotoxin accumulation in stored pome fruit [34], we included R. glutinis strain TY1, which we isolated from the wheat grains, in our mycotoxin-degradation assay. The analysis of $\mathrm{AFB}_{1}$ persistence in PDB medium was performed as follows. R. glutinis TY1 was grown overnight in $50 \mathrm{~mL}$ PDB with shaking at $28^{\circ} \mathrm{C}$. The culture was centrifuged for $5 \mathrm{~min}$ at $8000 \times g$, the cells were resuspended in $\mathrm{PDB}$, and their concentration was adjusted to $1 \times 10^{8} \mathrm{CFU} / \mathrm{ml}$. A 20-mL aliquot of this cell suspension was incubated on an orbital shaker for 3 days at $28^{\circ} \mathrm{C}$ in a $100-\mathrm{mL}$ flask in the presence of $250 \mathrm{ng} / \mathrm{mL}$ of $\mathrm{AFB}_{1}$. Controls included PDB medium only with $250 \mathrm{ng} / \mathrm{mL}$ of $\mathrm{AFB}_{1}$ and $\mathrm{PDB}$ without $\mathrm{AFB}_{1}$ inoculated with $R$. glutinis TY1 at the same cell concentration. Yeast growth was monitored on a daily basis by recording $\mathrm{OD}_{600}$ in the Nanodrop One spectrophotometer. At the same time points, the time course of $\mathrm{AFB}_{1}$ degradation was analyzed by high-performance liquid chromatography (HPLC).

$\mathrm{AFB}_{1}$ degradation by the $R$. glutinis TY1 isolate was also examined in stored wheat grains. Briefly, $10 \mathrm{~g}$ of surface-disinfected wheat grains were contaminated with $\mathrm{AFB}_{1}$ (final concentration $250 \mathrm{ng} / \mathrm{g}$ ) and inoculated with strain TY1 (final concentration $1 \times 10^{8}$ cells/g) on Petri dishes. Controls consisted of noninoculated wheat grains with and without $\mathrm{AFB}_{1}$ and TY1-inoculated grains without $\mathrm{AFB}_{1}$. The plates were prepared in triplicate and kept at $28^{\circ} \mathrm{C}$ for up to 3 days. Then, the grain samples were freeze-dried and milled to a fine powder with a grain grinder. $\mathrm{AFB}_{1}$ was extracted after 24,48 , and $72 \mathrm{~h}$ and samples were analyzed quantitatively by HPLC. Experiments were performed three times.

\subsection{HPLC Analysis}

For $\mathrm{AFB}_{1}$ extraction from $\mathrm{PDB}$ broth, the samples were centrifuged at $8000 \times g$ for $5 \mathrm{~min}$ to pellet out the cells, and $2 \mathrm{~mL}$ of the supernatant was mixed with $2 \mathrm{~mL}$ of chloroform and vortexed for $15 \mathrm{~min}$. After discarding the upper phase, the chloroform phase was dried at $50{ }^{\circ} \mathrm{C}$ under a stream of nitrogen gas. For the mycotoxin analysis from wheat grains, $2.5 \mathrm{~g}$ of the ground seeds were mixed with $10 \mathrm{~mL}$ of $84: 16(v / v)$ acetonitrile:water and placed in an orbital shaker at $200 \mathrm{rpm}$ for $1 \mathrm{~h}$ at room temperature. After centrifugation at $8500 \times g$ for $15 \mathrm{~min}, 2 \mathrm{~mL}$ of the supernatant was passed through a Supel ${ }^{\mathrm{TM}}$ TOX AflaZea column (Supelco, Bellefonte, PA, USA); then, the collected sample was evaporated by nitrogen stream at $50{ }^{\circ} \mathrm{C}$.

The dried samples were reconstituted in $900 \mu \mathrm{L}$ of $10 \%$ acetonitrile and $100 \mu \mathrm{L}$ of trifluoroacetic acid solution ( $70 \%$ water, $20 \%$ trifluoroacetic acid and $10 \%$ acetic acid $(v / v))$ for $15 \mathrm{~min}$ at $50{ }^{\circ} \mathrm{C}$. After incubation, the samples were filtered through a $0.22-\mu \mathrm{m}$ PTFE membrane filter, and quantitatively analyzed by injection of $30 \mu \mathrm{L}$ into a reversed phase 
HPLC/UHPLC system (Waters ACQUITY Arc, Milford, MA, USA) with gradient elution of $70 \%$ water, $15 \%$ acetonitrile and $15 \%$ methanol at $1 \mathrm{ml} / \mathrm{min}$ through a Kinetex $3.5 \mu \mathrm{m}$ XB$\mathrm{C}_{18}(150 \times 4.1 \mathrm{~mm})$ column (Phenomenex, USA). The column temperature was maintained at $35^{\circ} \mathrm{C}$. Three noncontaminated PDB and/or wheat grain samples were spiked with $\mathrm{AFB}_{1}$ standard solution at three concentrations to construct calibration curves, which were used for mycotoxin quantification. The $\mathrm{AFB}_{1}$ peak was detected with a fluorescence detector (excitation at $365 \mathrm{~nm}$ and emission at $455 \mathrm{~nm}$ ) and quantified by comparing with calibration curves of the mycotoxin standard.

\subsection{Statistical Analysis}

Data presented in the figures are mean values of three independent experiments. Standard errors of the mean (SEM) are presented. Differences among treatments were analyzed by one-way analysis of variance followed by Duncan's multiple range test to determine treatment effects, as well as significant differences between the strains (SPSS 16.0 software). $\mathrm{AFB}_{1}$ persistence in the biodegradation assays was analyzed by one-way analysis of covariance to determine statistically significant differences between treatment effects on mycotoxin concentration controlling for time (covariance).

\section{Results and Discussion}

\subsection{Composition of Epiphytic and Endophytic Microbiota Associated with Stored Wheat Grain}

After quality filtering and removing chimeric, chloroplast and mitochondrial sequences, $682,47816 \mathrm{~S}$ and 1,044,499 ITS sequences were retained and assigned to 63,108 and 114,849 bacterial and fungal OTUs, respectively.

The taxonomic assignment of 63,108 bacterial OTUs revealed 22 phyla in the epiphytic and endophytic datasets, including Proteobacteria, the predominant in the datasets $(48.1 \%$ and $67.8 \%)$, followed by Actinobacteria (10.4\% and $18.8 \%)$, Firmicutes (13.7\% and $10.6 \%$ ), Bacteroidetes (9.2\% and $2.1 \%$ ) and Acidobacteria ( $0.2 \%$ and $0.1 \%)$, respectively (Figure $1 \mathrm{~A})$. Planctomycetes $(7.7 \%)$ and Chloroflexi $(2.7 \%)$ were found only as endophytes. The relative abundance of the epiphytic and endophytic bacterial microbiota varied at the genus level. The most abundant endophytic bacterial genera were Pantoea (7.5\%), Ohtaekwangia (5.8\%), Bacillus (4.9\%), Burkholderia (4.0\%), Actinobacteria (3.9\%), Enterobacter (3.7\%), Pseudomonas (3.1\%), Caulobacter (2.6\%), Staphylococcus (2.5\%), Sphingomonas (1.9\%), Wolbachia (1.8\%), Klebsiella (1.6\%), Micrococcus (1.5\%), Stenotrophomonas (1.3\%), Massilia (1.1\%), Paenibacillus $(1.0 \%)$, and Ralstonia (1.0\%) (Figure 1B). In the epiphytic bacterial community, the most abundant genera were Pantoea (20.3\%), Sphingomonas (10.2\%), Pseudomonas (8.1\%), Massilia (8.5\%), Curtobacterium (4.3\%), Microbacter (4.3\%), Paracoccus (3.3\%), Agrococcus (2.7\%), Enterobacter (2.7\%), Paenibacillus (2.1\%), Enhydrobacter (2.0\%), Hymenobacter (1.4\%), Anaerococcus $(1.4 \%)$, Acinetobacter $(1.2 \%)$, Brevundimonas $(1.1 \%)$, and Bacillus $(0.8 \%)$ (Figure 1B). These findings support earlier studies on seed-associated microbiota, where the bacterial taxa Pantoea, Bacillus, Enterobacter, and Pseudomonas were detected as both endophytic and epiphytic microorganisms $[12,13,35,36]$.

Among all of the identified bacterial taxa, Ruminococcaceae, SG8-4, Anaerolineaceae, Devosia, Actinobacteria, Diplorickettsiaceae, Pseudoalteromonas, Ohtaekwangia, Comamonas, and Klebsiella were significantly $(p<0.05)$ higher in the wheat grain endosphere than in epiphytic communities. In contrast, bacterial epiphytic taxa such as Microbacteriaceae, Sphingomonas, Agrococcus, Curtobacterium, Massilia, Hymenobacter, Methylobacterium, Paracoccus, Pseudomonas, Clavibacter, Pantoea, Enterobacteriaceae, and Arthrobacter were significantly higher $(p<0.05)$ as epiphytes than as endophytes (Figure 1B). The differentially abundant or unique taxa characterizing the endophytic niche of wheat grains were mostly unidentified bacterial species. This finding highlights the lack of information that exists on the microorganisms that inhabit the endosphere of seeds and their role in plant growth, development, and health. 

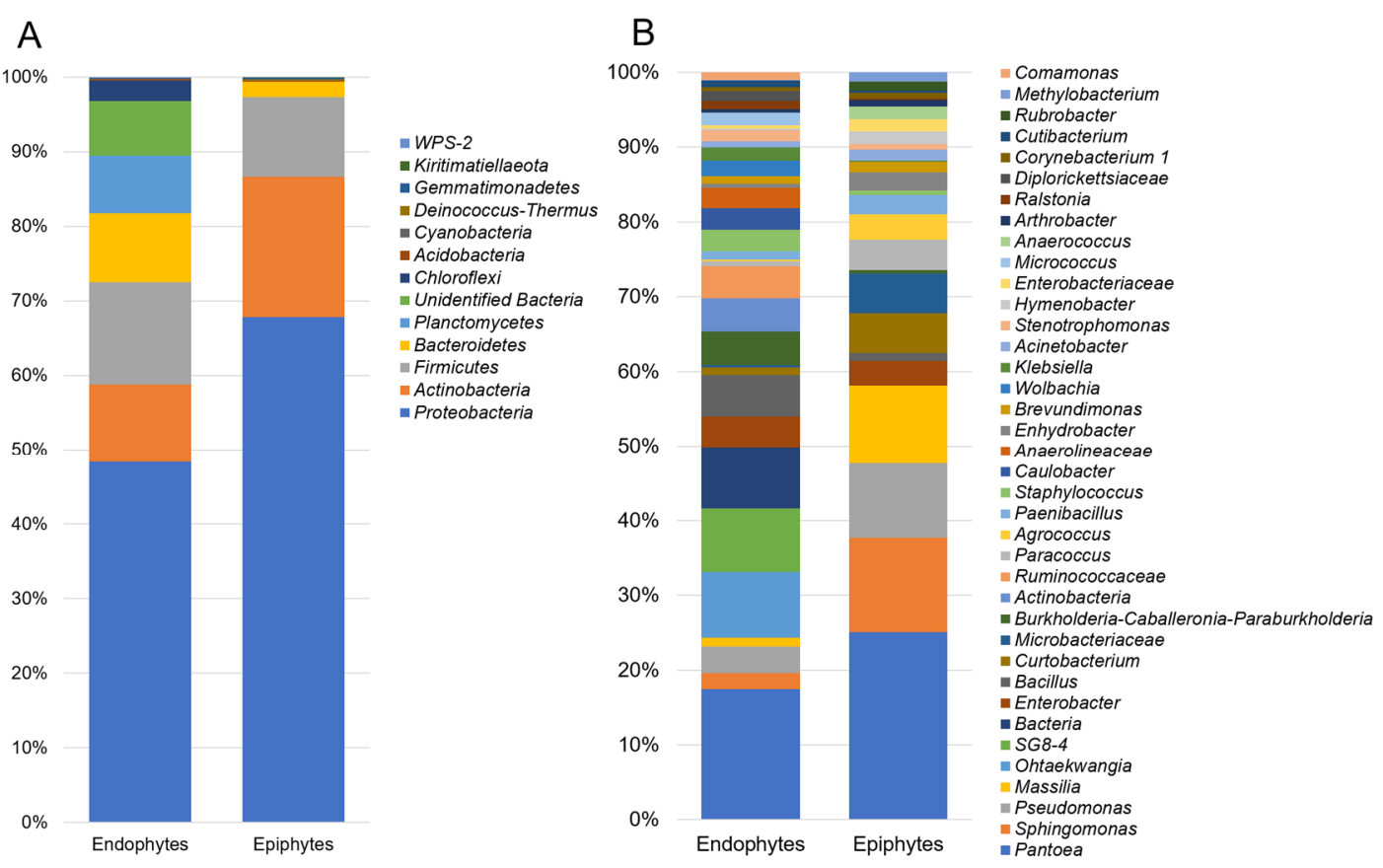

Figure 1. Bar charts showing the relative abundance of most dominant bacterial phyla (A) and genera (B) among endophytes and epiphytes detected in stored wheat grain samples using high-throughput sequencing technology.

The fungal communities were dominated by a few phyla. Ascomycota was the most abundant phylum, with a relative abundance of $95.3 \%$ and $72.9 \%$ in the endophytic and epiphytic communities, respectively. The relative abundance of Basidiomycota was much higher in the epiphytic fungal community $(26.1 \%)$ relative to fungal endophytic community $(4.3 \%)$ (Figure 2A). At the genus level, OTUs of the fungal endophytes were assigned to Alternaria (76.8\%), Russula (3.4\%), Stemphylium (11.8\%), Aspergillus (1.9\%), Epicoccum (1.0\%), Cladosporium (0.9\%), Pyrenophora (0.5\%), Mycosphaerella (0.4\%), Paradendryphiella (0.4\%), Sporobolomyces (0.1\%) and Filobasidium ( $0.1 \%)$, and epiphytes annotated to Alternaria (50.3\%), Sporobolomyces (9.5\%), Filobasidium (8.8\%), Vishniacozyma (4.2\%), Mycosphaerella (3.6\%), Stemphylium (3.5\%), Cladosporium (10.5\%), Epicoccum (1.4\%), Dioszegia (1.1\%), Aspergillus $(0.8 \%)$, Aureobasidium (0.7\%), Paradendryphiella (0.2\%), Russula (0.1\%) and Pyrenophora $(0.1 \%)$ (Figure 2B).

The Shannon $\alpha$-diversity was higher in the epiphytic community of both bacteria and fungi than it was in the endophytic community (Figure 3). A two-sample t-test based on the Shannon index revealed a significant difference between the structure of the endophytic and epiphytic bacterial $(p=0.001)$ and fungal $(p=0.001)$ community (Table S4). PCoA was used to measure the dissimilarity of the epiphytic and endophytic microbial communities of wheat grains (Figure 4). The structure of the epiphytic and endophytic bacterial communities were clearly different as evidenced by their evident separation in the PCoA plot, and the same was true for the structure of the epiphytic and endophytic fungal communities. The ANOSIM test (nonparametric 999 permutations) of variance analysis also indicated that the composition of epiphytic and endophytic bacterial and fungal communities was significantly different $\left(R^{2}=0.89, p=0.001\right.$ and $R^{2}=0.85$, $p=0.001)$, respectively. 
A

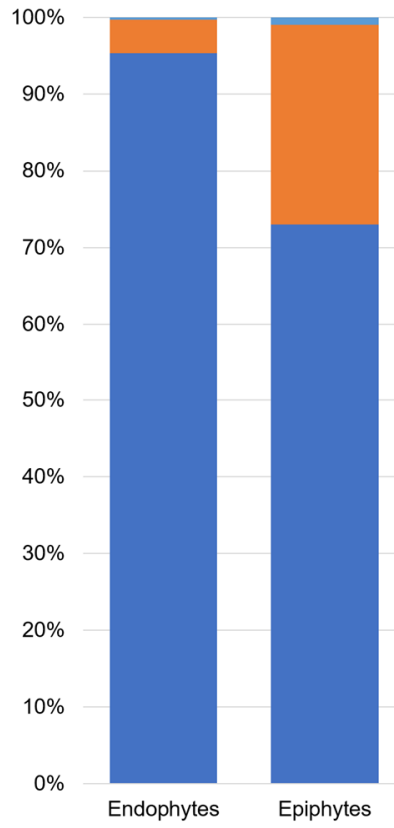

B

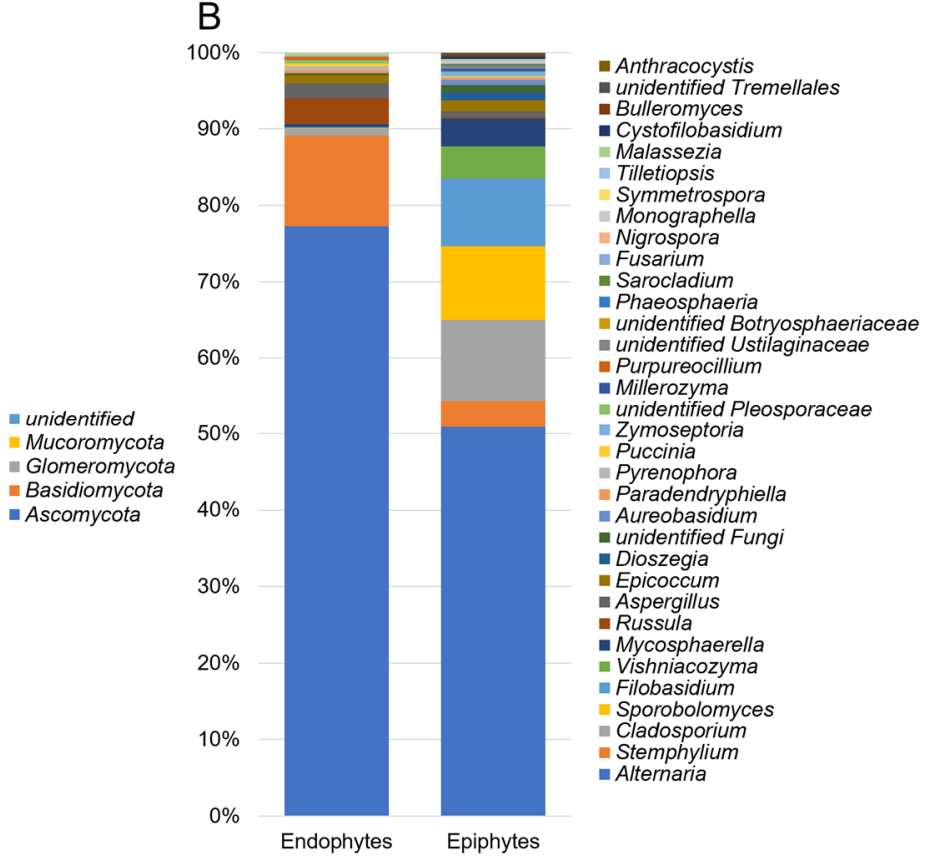

Figure 2. Relative abundance of fungal phyla (A) and genera (B) among endophytes and epiphytes detected in grain samples using high-throughput sequencing technology.


Figure 3. Alpha diversity analysis (based on Shannon diversity index) of the bacterial (A) and fungal (B) epiphytes and endophytes in stored wheat grain samples. The centered square represents the mean, black line inside the box represents the median, and circles indicate outliers. 


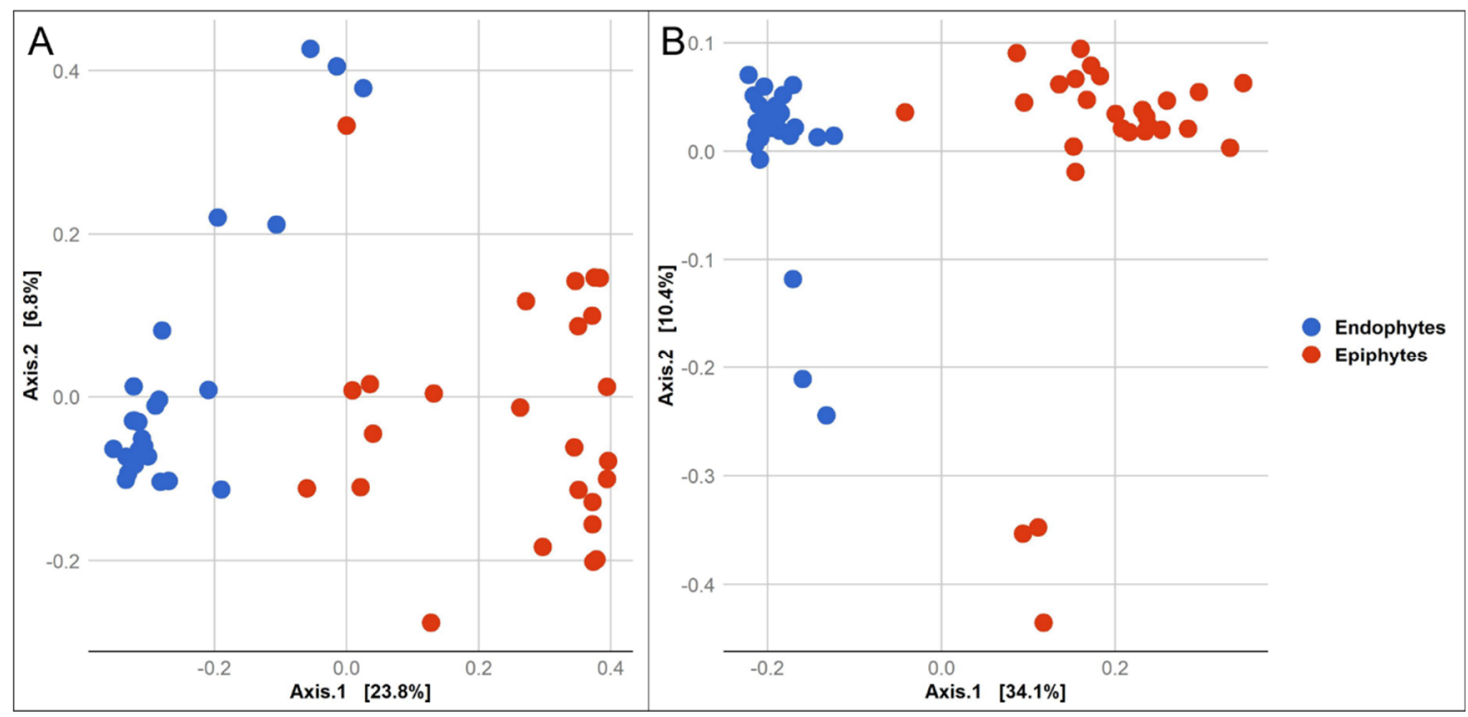

Figure 4. Principal coordinate analysis (PCoA) based on the beta diversity Bray Curtis dissimilarity metrics, showing the distance in the wheat grain-associated bacterial (A) and fungal (B) communities between endophytic and epiphytic microbes.

Endophytic microbial diversity was significantly lower than that of the epiphytic microbiota. This can be attributed to the need for seed endophytes to pass through the plant ecological, and physiological sieve to become internalized and tolerate harsh seed conditions, including a high level of desiccation.

3.2. Microbe Isolation from Stored Grains and the Antagonistic Activity of Selected Isolates against Mycotoxigenic Fungal Pathogens

A total of 159 bacterial isolates were cultured from wheat grains and identified by $16 \mathrm{~S}$ rRNA sequencing; 118 of which were isolated from the grain surface as epiphytes and 41 as endophytes from the inner tissues of the grains. Bacillus spp. were dominant among cultured bacterial epiphytes (53.4\%), followed by Pseudomonas spp. (10\%), Pantoea spp. (6.8\%), Paenibacillus spp. (5\%), and Staphylococcus spp. and Enterobacter spp. (3.4\% for each genus) (Figure 5A). Diversity among endophytes was lower than for epiphytes at the taxonomic level of genus. Similarly to bacterial epiphytes, however, most endophytes isolated from stored wheat grains belonged to the genera Bacillus (46.3\%) and Pseudomonas $(14.6 \%)$ (Figure 5A). These observations are consistent with previous studies of seedassociated endophytic bacteria, where Bacillus and Pseudomonas were the genera most frequently found in plant seeds [37]. In a study on barley seed endophytes, most endophytic bacteria were assigned to the same genera, with Bacillus and Pseudomonas being retrieved from the seeds placed under selective pressure for nitrogen-fixing microorganisms [38].

Among mold and yeast strains isolated from stored grains, 104 epiphytes and 37 endophytes were identified by ITS and D1/D2 region sequencing. The epiphytic fungal communities were the richest and most abundant, while richness and diversity in the endophytes was much lower. Most of the epiphytic and endophytic filamentous fungi were identified as Alternaria, Aspergillus, Fusarium, and Penicillium species. Filobasidium, Cryptococcus, Rhodotorula, and Candida species dominated both epiphytic and endophytic yeast cultures isolated from grains (Figure 5B). In general, the composition of the bacterial and fungal taxa isolated from wheat grains in our study were in agreement with previous reports $[12,13,36,37,39]$. The culturing results were also consistent with the results obtained by high-throughput sequencing in the present study. Bacterial communities assigned to Pantoea, Pseudomonas, Bacillus, Enterobacter, and Paenibacillus spp., and fungal microbiota comprising Alternaria, Aspergillus, Fusarium, and Filobasidium spp. were identified as the common genera among the members of the shared epiphytic and endophytic microbiota of stored wheat seeds. 

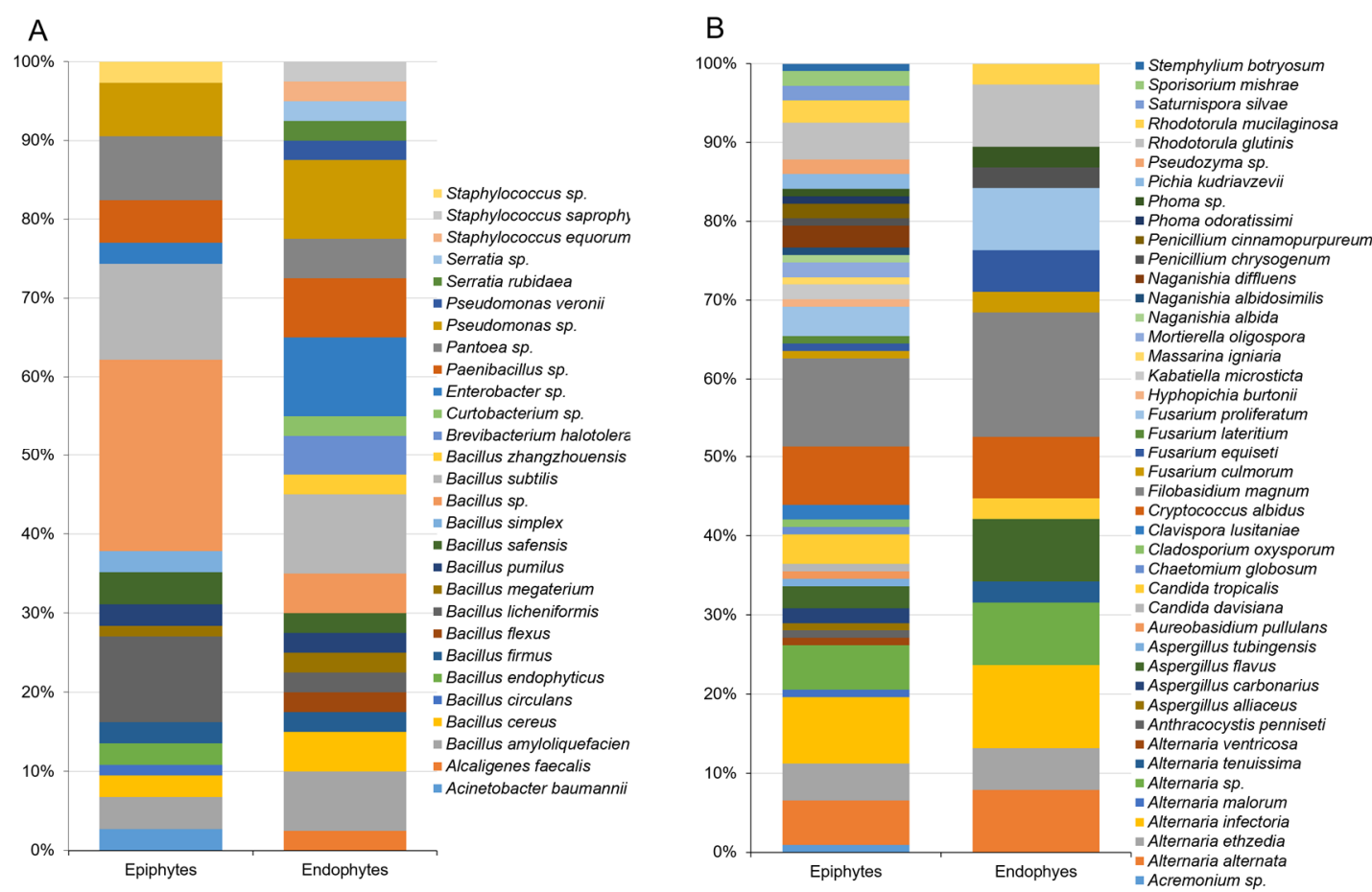

Figure 5. Relative abundance of bacterial (A), and fungal (B) species isolated by plating from epiphytic and endophytic microflora of stored wheat grains. The isolates were identified by sequencing the $16 \mathrm{~S}$ rRNA gene in bacteria, ITS region and D1/D2 domain of large-subunit rDNA in filamentous fungi and yeasts, respectively. The sequences were determined via BLAST matches to the NCBI database.

In vitro screening of microbial isolates in dual-culture assays with Aspergillus flavus, Fusarium proliferatum, and Alternaria infectoria revealed only four Bacillus isolates that exhibited considerable inhibitory activity against the tested mycotoxigenic fungi (Supplementary Materialis Figure S1). These were two endophytes (B. amyloliquefaciens strain EnB28 and B. amyloliquefaciens strain EnB29) and two epiphytes (B. licheniformis strain EpV5 and $B$. subtilis strain EpV29). The isolates appeared to secrete antifungal substances that were capable of inhibiting fungal growth (Figure S2). The mean values of pathogen growth inhibition fluctuated between 23 and 40\% against Aspergillus flavus, 23 and 41\% against F. proliferatum, and 38 and $54 \%$ against Alternaria infectoria. In contrast, a volatile organic compound (VOC) assay revealed that none of the isolated exhibited inhibitory activity against any of the tested fungi. These results conflict with previous studies in which VOC inhibitory activity by Bacillus strains against Aspergillus, Fusarium, and Alternaria species has been reported [40-42].

To validate our in vitro results on the biocontrol potential of Bacillus isolates, we designed a simple bioassay suitable for analyzing antagonistic activity of the selected Bacillus strains against mycotoxigenic fungi in stored grains. All of the bacterial isolates tested significantly reduced fungal growth in grains compared to untreated controls $(p<0.05$, Figure 6). The tested Bacillus species exhibited the strongest antagonistic activity against $F$. proliferatum, resulting in an up to a $3.59 \log _{10} \mathrm{CFU} / \mathrm{g}$ reduction in the fungal population compared to control samples. Additionally, up to a 2.45 and $1.76 \log _{10} \mathrm{CFU} / \mathrm{g}$ decrease was recorded for Aspergillus flavus and Alternaria infectoria, respectively. Bacillus spp., such as $B$. amyloliquefaciens and $B$. subtilis, have been previously identified and characterized as antagonistic toward Fusarium spp. on wheat [14,43-49]. Few studies, however, have been conducted on the antagonistic potential of Bacillus isolates against Aspergillus and/or Alternaria pathogens on wheat [50]. Bacillus strains are well known for their ability to produce a wide range of potent antimicrobial lipopeptides, including iturins, surfactins, fengycins, polymyxins, and others, that have broad effects on phytopathogens [51-53]. Although they were not characterized in this study, some of these compounds could be 
responsible for the bacterial inhibitory activity against the tested fungal pathogens. In addition to lipopeptides, other antimicrobial compounds produced by Bacillus strains, such as polyketides and lithium enzymes [54], may also be involved in the antifungal activity observed both in vitro and in vivo. Determining the source of the antimicrobial activity of the Bacillus isolates against the tested fungal pathogens will require further study.

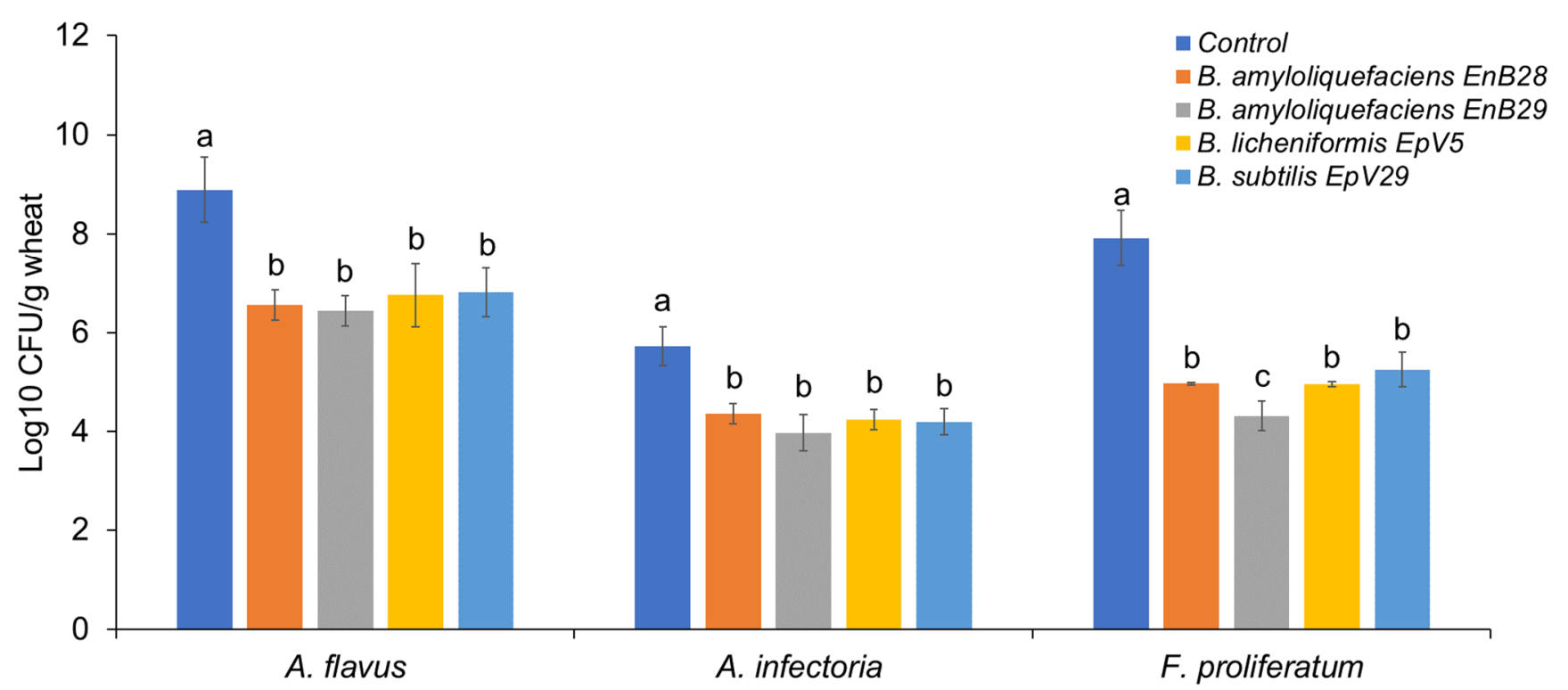

Figure 6. Antagonistic activity of four selected bacterial isolates against three mycotoxigenic fungal pathogens in stored wheat grains. Data are means of at least three independent repetitions \pm standard error. One-way ANOVA differences were considered significant when $p<0.05$. Different letters above the error bars indicate statistically significant differences among treatments in each group as determined based on Duncan's multiple range test.

In sharp contrast to the bacterial strains, yeast isolates obtained from wheat seeds exhibited no inhibition of mycotoxigenic fungal growth in vitro in the dual-culture assay. Further evaluation of the yeast strains by screening for activity on colonized wheat grains revealed four species that exhibit antagonistic properties against the tested fungal pathogens. The yeast isolates were Naganishia albidosimilis (strain D1), Naganishia albida (strain D34), Cryptococcus albidus (strain D37), and Rhodotorula glutinis (strain TY1). As shown in Figure 7, the growth of F. proliferatum on wheat seeds was markedly limited when the grains were pretreated with yeast cell suspensions. Among them, R. glutinis TY1 displayed a strong ability to protect the stored grains against $F$. proliferatum by reducing the population of the fungal load by $3.11 \log _{10} \mathrm{CFU} / \mathrm{g}$. This strain also displayed the strongest antagonistic activity against Aspergillus flavus with a reduction of $1.33 \log _{10} \mathrm{CFU} / \mathrm{g}$ in the fungal load compared to the untreated control. All four yeast isolates, however, had a relatively weak effect on Alternaria infectoria.

The differential efficacy observed between the in vitro and in vivo screening of yeast isolates could be explained by the different abilities of the potential biocontrol strains to produce secondary metabolites in a growth medium a vs. on plant material $[12,55]$. Therefore, determination of an inhibition zone by dual-culture assay, often considered a preliminary test for selecting antagonistic strains, can be misleading [12]. 


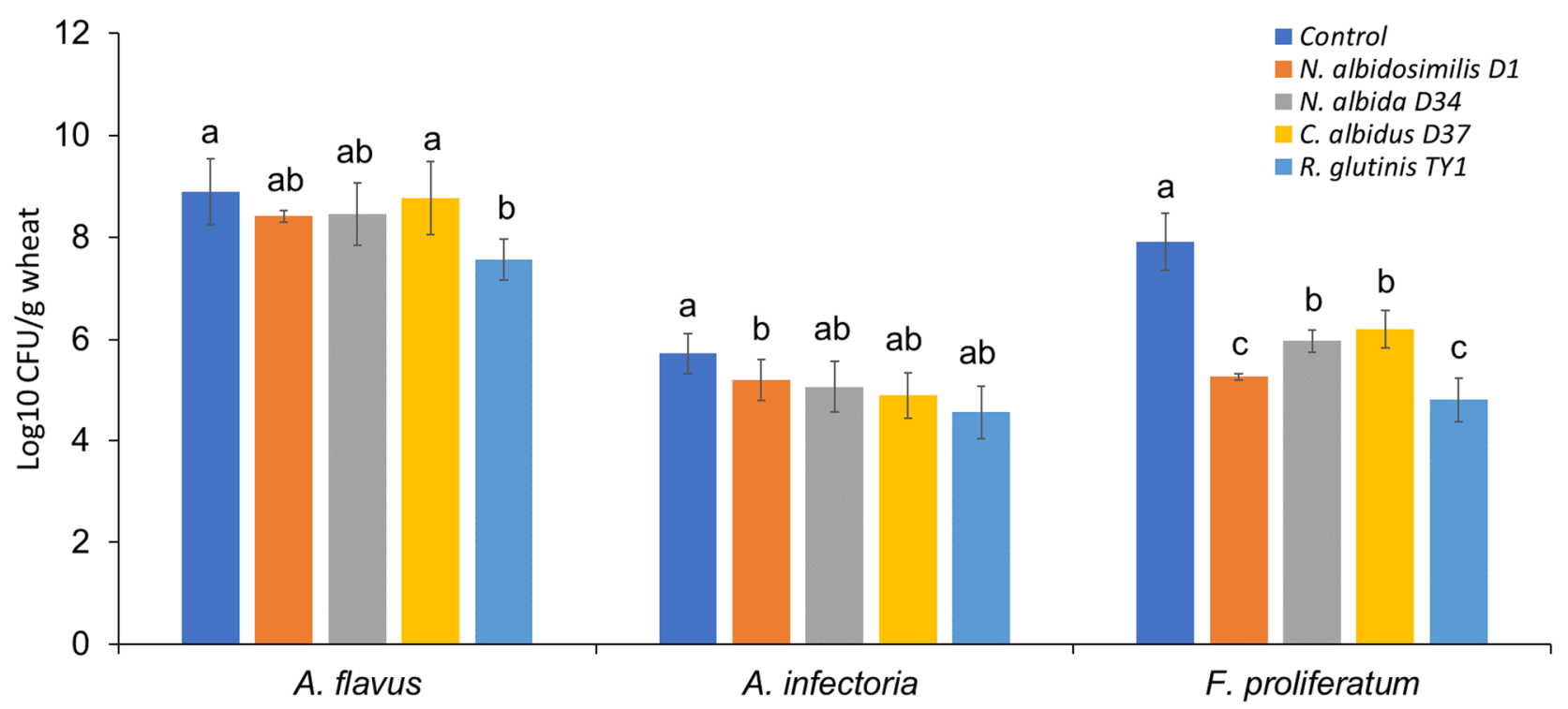

Figure 7. Antagonistic activity of four selected yeast isolates against three mycotoxigenic fungi in stored wheat grains. Error bars represent standard error of three independent biological replicates. Different letters above the error bars indicate statistically significant differences among treatments in each group at $p<0.05$, as determined based on Duncan's multiple range test.

\subsection{Mycotoxin-Degrading Activity of the Yeast Rhodotorula glutinis Strain TY1}

In vitro growth kinetics of $R$. glutinis TY1 in the absence and presence of $A_{F B}$ were similar and characterized by exponential growth until the third day of incubation (Figure 8). Subsequent HPLC analysis indicated that the recovery of $\mathrm{AFB}_{1}$ was lower when R. glutinis strain TY1 was incubated in PDB medium amended with $250 \mathrm{ng} / \mathrm{mL} \mathrm{AFB}{ }_{1}$. Reductions of 47,61 , and $75 \%$ in $\mathrm{AFB}_{1}$ recovery were observed on days 1,2, and 3 of incubation, respectively, compared to the control (Figure $8 \mathrm{~A}$ ). In stored grain samples artificially contaminated with $\mathrm{AFB}_{1}$, a decrease in mycotoxin levels was recorded throughout the time course of the experiment for TY1-treated seeds compared to untreated controls. The presence of the yeast strain significantly lowered mycotoxin levels in grain samples by 26.5 , 51 , and $65 \%$ on days 1,2 , and 3 of the experiment, respectively, compared to untreated controls (Figure $8 \mathrm{~B}$ ).

$\mathrm{AFB}_{1}$ is a mycotoxin that presents an economic challenge to a wide range of agricultural products and food industries worldwide, and a health hazard to consumers. The reduction of aflatoxin contamination in commodities through the application of antagonistic microorganisms has long been known, and is still an active field of research [56]. Castoria et al. [34] showed that $R$. glutinis can decrease patulin in vitro and in apple fruit infected by Penicillium expansum. Their data indicated that $R$. glutinis yeast cells metabolize patulin and/or negatively affect its accumulation or synthesis. Other studies have reported that the biocontrol yeast Sporobolomyces sp. degrades patulin in vitro under aerobic conditions and converts it into less toxic breakdown products $[57,58]$. Based on the results obtained in the current study, it appears that $R$. glutinis can metabolize and/or degrade $\mathrm{AFB}_{1}$ in vitro and in stored wheat grains. The mechanism responsible for this activity, however, still needs to be confirmed. Moreover, characterization of the final breakdown products of $\mathrm{AFB}_{1}$ and their toxicological properties also need to be investigated, to ensure the safety of using this yeast isolate as a postharvest application on stored grains. 

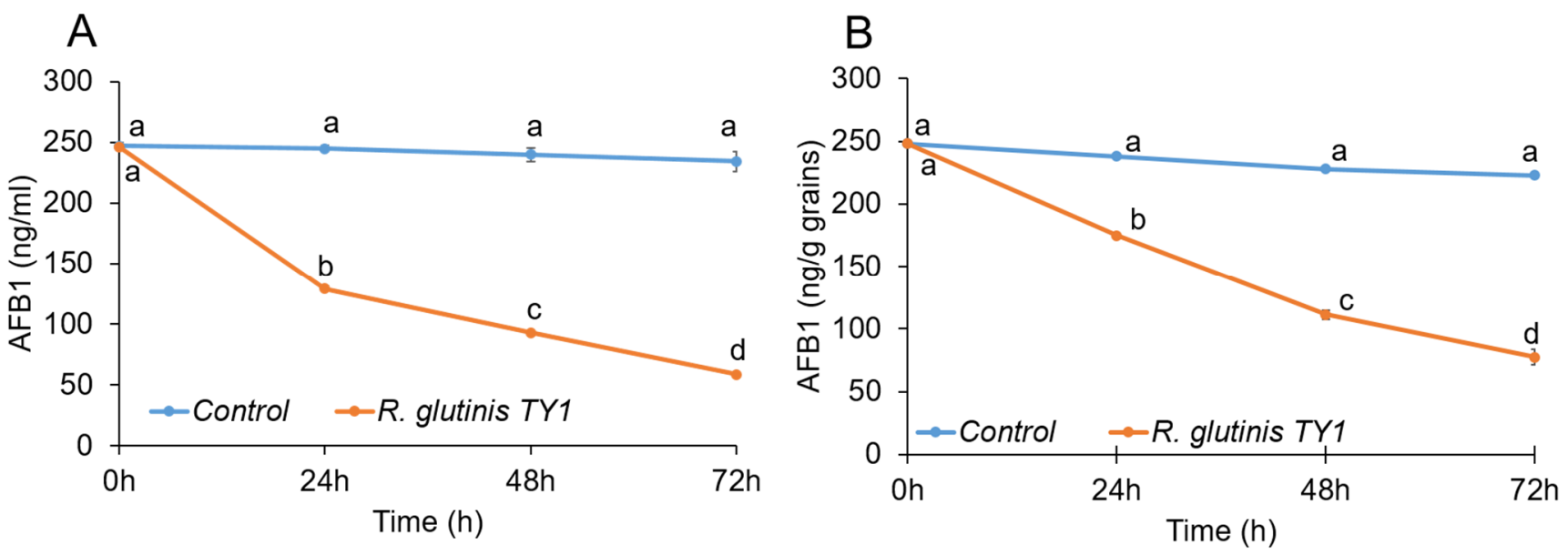

Figure 8. Effect of R. glutinis TY1 strain on AFB1 degradation in PDB medium (A) and wheat grains (B). The time course of AFB1 degradation was monitored by HPLC. Error bars represent the standard error of the mean (SEM) across three independent replicates. One-way ANCOVA was conducted to determine a statistically significant difference between treatment and control on mycotoxin concentration controlling for time (covariance). Time significantly differed in its effect on treatment and control $(p<0.0001)$. Testing for each time point using ANOVA is an evident that only time zero does not differ between control and treatment. Different letters above the error bars indicate statistically significant differences at $p<$ 0.05 , as determined using the Duncan's multiple range test.

\section{Conclusions}

In summary, we identified the composition of stored wheat grain-associated epiphytic and endophytic microbiota using high-throughput sequencing of amplicons. Large numbers of microorganisms forming epiphytic and endophytic communities often possess beneficial characteristics, including antagonistic activity against fungal pathogens. Indeed, we found that stored wheat seeds harbor bacterial and yeast communities with antagonistic potential and biodegradation ability against mycotoxigenic fungi and their respective toxins. Application of such microbes, which are adapted to their host plant, may represent an efficient fungal disease control strategy for stored grains, as well as other agricultural commodities. A better understanding of the antagonistic mechanism of these microorganisms, and the role they play in the microbiome of seeds, may assist in the development of novel antifungal biocontrol approaches to replace traditionally used synthetic fungicides.

Supplementary Materials: The following are available online at https:/ / www.mdpi.com/article/10 .3390/jof7090781/s1, Figure S1: Graphical representation of antagonistic activity of selected bacterial isolates against mycotoxigenic fungal pathogens in vitro; Figure S2: Antagonistic activity of Bacillus amyloliquefaciens (strain EnB28) against three mycotoxigenic fungal pathogens in vitro; Table S1: List of primers used in the study; Table S2: List of bacterial taxa with significant differential abundance according to Kruskal-Wallis test; Table S3: List of fungal taxa with significant differential abundance according to Kruskal-Wallis test; Table S4: Summary of Shannon index data.

Author Contributions: Conceptualization, M.K.S., M.W., E.S. and S.D.; methodology, M.K.S., A.A., V.Z. and S.S.; software, A.A.; validation, M.K.S., A.A. and S.S.; formal analysis, M.K.S., S.S. and A.A.; investigation, M.K.S., A.A., S.D. and E.S.; data curation, M.K.S. and A.A.; writing-original draft preparation, M.K.S., A.A., S.D. and E.S.; writing-review and editing, M.W.; supervision, S.D. and E.S.; project administration, V.Z. All authors have read and agreed to the published version of the manuscript.

Funding: This research was funded by the Chief Scientist of the Israeli Ministry of Agriculture and Rural Development, grant number 20-06-0055.

Data Availability Statement: The raw sequence files supporting the findings of this article are available in the NCBI Sequence Read Archive (SRA) under the BioProject ID PRJNA756939. 
Acknowledgments: We thank Elazar Quinn for his assistance during the wheat grains samples collection from storage facilities.

Conflicts of Interest: The authors declare no conflict of interest.

\section{References}

1. Links, M.G.; Demeke, T.; Gräfenhan, T.; Hill, J.E.; Hemmingsen, S.M.; Dumonceaux, T.J. Simultaneous profiling of seed-associated bacteria and fungi reveals antagonistic interactions between microorganisms within a shared epiphytic microbiome on Triticum and Brassica seeds. New Phytol. 2014, 202, 542-553. [CrossRef]

2. Placinta, C.M.; D'Mello, C.P.F.; MacDonald, A.M.C. A review of worldwide contamination of cereal grains and animal feed with Fusarium mycotoxins. Anim. Feed Sci. Technol. 1999, 78, 21-37. [CrossRef]

3. Magan, N.; Aldred, D.; Mylona, K.; Lambert, R.J.W. Limiting mycotoxins in stored wheat. Food Addit. Contam. Part. A 2010, 27, 644-650. [CrossRef] [PubMed]

4. Magan, N.; Hope, R.; Cairns, V.; Aldred, D. Post-harvest fungal ecology: Impact of fungal growth and mycotoxin accumulation in stored grain. Eur. J. Plant. Pathol. 2003, 109, 723-730. [CrossRef]

5. Ferrigo, D.; Raiola, A.; Causin, R. Fusarium toxins in cereals: Occurrence, legislation, factors promoting the appearance and their management. Molecules 2016, 21, 627. [CrossRef] [PubMed]

6. McCormick, S.P.; Stanley, A.M.; Stover, N.A.; Alexander, N.J. Trichothecenes: From simple to complex mycotoxins. Toxins 2011, 3, 802-814. [CrossRef] [PubMed]

7. Lee, H.J.; Ryu, D. Worldwide occurrence of mycotoxins in cereals and cereal-derived food products: Public health perspectives of their co-occurrence. J. Agric. Food Chem. 2017, 65, 7034-7051. [CrossRef] [PubMed]

8. Streit, E.; Naehrer, K.; Rodrigues, I.; Schatzmayr, G. Mycotoxin occurrence in feed and feed raw materials worldwide: Long-term analysis with special focus on Europe and Asia. J. Sci. Food Agric. 2013, 93, 2892-2899. [CrossRef]

9. Chen, Y.; Kistler, H.C.; Ma, Z. Fusarium graminearum trichothecene mycotoxins: Biosynthesis, regulation, and management. Annu. Rev. Phytopathol. 2019, 57, 15-39. [CrossRef]

10. Gdanetz, K.; Trail, F. The wheat microbiome under four management strategies, and potential for endophytes in disease protection. Phytobiomes 2017, 1, 158-168. [CrossRef]

11. Mousa, W.K.; Shearer, C.; Limay-Rios, V.; Ettinger, C.L.; Eisen, J.A.; Raizada, M.N. Root-hair endophyte stacking in finger millet creates a physicochemical barrier to trap the fungal pathogen Fusarium graminearum. Nat. Microbiol. 2016, 1, 16167. [CrossRef]

12. Comby, M.; Gacoin, M.; Robineau, M.; Rabenoelina, F.; Ptas, S.; Dupont, J.; Profizi, C.; Baillieul, F. Screening of wheat endophytes as biological control agents against Fusarium head blight using two different in vitro tests. Microbiol. Res. 2017, 202, 11-20. [CrossRef]

13. Díaz Herrera, S.; Grossi, C.; Zawoznik, M.; Groppa, M.D. Wheat seeds harbour bacterial endophytes with potential as plant growth promoters and biocontrol agents of Fusarium graminearum. Microbiol. Res. 2016, 186, 37-43. [CrossRef]

14. Baffoni, L.; Gaggia, F.; Dalanaj, N.; Prodi, A.; Nipoti, P.; Pisi, A.; Biavati, B.; Di Gioia, D. Microbial inoculants for the biocontrol of Fusarium spp. in durum wheat. Bmc Microbiol. 2015, 15, 1-10. [CrossRef]

15. Leah Musyimi, S.; Wanjohi Muthomi, J.; Devi Narla, R.; Maina Wagacha, J. Efficacy of Biological Control and Cultivar Resistance on Fusarium Head Blight and T-2 Toxin Contamination in Wheat. Am. J. Plant Sci. 2012, 3, 599-607. [CrossRef]

16. Sadhasivam, S.; Britzi, M.; Zakin, V.; Kostyukovsky, M.; Trostanetsky, A.; Quinn, E.; Sionov, E. Rapid detection and identification of mycotoxigenic fungi and mycotoxins in stored wheat grain. Toxins 2017, 9, 302. [CrossRef] [PubMed]

17. Hanshew, A.S.; Mason, C.J.; Raffa, K.F.; Currie, C.R. Minimization of chloroplast contamination in $16 \mathrm{~S}$ rRNA gene pyrosequencing of insect herbivore bacterial communities. J. Microbiol. Methods 2013, 95, 149-155. [CrossRef]

18. Scibetta, S.; Schena, L.; Abdelfattah, A.; Pangallo, S.; Cacciola, S.O. Selection and experimental evaluation of universal primers to study the fungal microbiome of higher plants. Phytobiomes J. 2018, 2, 225-236. [CrossRef]

19. Bolger, A.M.; Lohse, M.; Usadel, B. Trimmomatic: A flexible trimmer for Illumina sequence data. Bioinformatics 2014, 30, 2114-2120. [CrossRef] [PubMed]

20. Zhang, J.; Kobert, K.; Flouri, T.; Stamatakis, A. PEAR: A fast and accurate Illumina Paired-End reAd mergeR. Bioinformatics 2014, 30, 614-620. [CrossRef] [PubMed]

21. Masella, A.P.; Bartram, A.K.; Truszkowski, J.M.; Brown, D.G.; Neufeld, J.D. PANDAseq: Paired-end assembler for Illumina sequences. Bmc Bioinform. 2012, 13, 31. [CrossRef] [PubMed]

22. Edgar, R.C. Search and clustering orders of magnitude faster than BLAST. Bioinformatics 2010, 26, 2460-2461. [CrossRef]

23. McDonald, D.; Price, M.N.; Goodrich, J.; Nawrocki, E.P.; DeSantis, T.Z.; Probst, A.; Andersen, G.L.; Knight, R.; Hugenholtz, P. An improved Greengenes taxonomy with explicit ranks for ecological and evolutionary analyses of bacteria and archaea. ISME J. 2012, 6, 610-618. [CrossRef] [PubMed]

24. Rognes, T.; Flouri, T.; Nichols, B.; Quince, C.; Mahé, F. VSEARCH: A versatile open source tool for metagenomics. PeerJ 2016, 4, e2584. [CrossRef]

25. Caporaso, J.G.; Kuczynski, J.; Stombaugh, J.; Bittinger, K.; Bushman, F.D.; Costello, E.K.; Fierer, N.; Peña, A.G.; Goodrich, J.K.; Gordon, J.I.; et al. QIIME allows analysis of high-throughput community sequencing data. Nat. Methods 2010, 7, 335-336. [CrossRef] 
26. DeSantis, T.Z.; Hugenholtz, P.; Larsen, N.; Rojas, M.; Brodie, E.L.; Keller, K.; Huber, T.; Dalevi, D.; Hu, P.; Andersen, G.L. Greengenes, a chimera-checked 16S rRNA gene database and workbench compatible with ARB. Appl. Env Microbiol. 2006, 72, 5069-5072. [CrossRef]

27. Abarenkov, K.; Henrik Nilsson, R.; Larsson, K.-H.; Alexander, I.J.; Eberhardt, U.; Erland, S.; Høiland, K.; Kjøller, R.; Larsson, E.; Pennanen, T.; et al. The UNITE database for molecular identification of fungi-recent updates and future perspectives. New Phytol. 2010, 186, 281-285. [CrossRef]

28. Altschul, S.F.; Gish, W.; Miller, W.; Myers, E.W.; Lipman, D.J. Basic local alignment search tool. J. Mol. Biol. 1990, 215, 403-410. [CrossRef]

29. Paulson, J.N.; Stine, O.C.; Bravo, H.C.; Pop, M. Differential abundance analysis for microbial marker-gene surveys. Nat. Methods 2013, 10, 1200-1202. [CrossRef]

30. Bray, J.R.; Curtis, J.T. An ordination of the upland forest communities of southern Wisconsin. Ecol. Monogr. 1957, 27, 325-349. [CrossRef]

31. Lozupone, C.; Knight, R. UniFrac: A new phylogenetic method for comparing microbial communities. Appl. Env Microbiol. 2005, 71, 8228-8235. [CrossRef]

32. Kruskal, W.H.; Wallis, W.A. Use of ranks in one-criterion variance analysis. J. Am. Stat. Assoc. 1952, 47, 583-621. [CrossRef]

33. De, S.; Kaur, G.; Roy, A.; Dogra, G.; Kaushik, R.; Yadav, P.; Singh, R.; Datta, T.K.; Goswami, S.L. A simple method for the efficient isolation of genomic DNA from Lactobacilli isolated from traditional indian fermented milk (dahi). Indian J. Microbiol. 2010, 50, 412-418. [CrossRef] [PubMed]

34. Castoria, R.; Morena, V.; Caputo, L.; Panfili, G.; De Curtis, F.; De Cicco, V. Effect of the biocontrol yeast Rhodotorula glutinis strain LS11 on patulin accumulation in stored apples. Phytopathology 2005, 95, 1271-1278. [CrossRef] [PubMed]

35. Johnston-Monje, D.; Raizada, M.N. Conservation and diversity of seed associated endophytes in zea across boundaries of evolution, ethnography and ecology. PLoS ONE 2011, 6, e20396. [CrossRef] [PubMed]

36. Solanki, M.K.; Abdelfattah, A.; Britzi, M.; Zakin, V.; Wisniewski, M.; Droby, S.; Sionov, E. Shifts in the composition of the microbiota of stored wheat grains in response to fumigation. Front. Microbiol. 2019, 10, 1098. [CrossRef] [PubMed]

37. Truyens, S.; Weyens, N.; Cuypers, A.; Vangronsveld, J. Bacterial seed endophytes: Genera, vertical transmission and interaction with plants. Env Microbiol. Rep. 2015, 7, 40-50. [CrossRef]

38. Zawoznik, M.S.; Vázquez, S.C.; Herrera, S.M.D.; Groppa, M.D. Search for endophytic diazotrophs in barley seeds. Braz. J. Microbiol. 2014, 45, 621-625. [CrossRef]

39. Karlsson, I.; Friberg, H.; Kolseth, A.-K.; Steinberg, C.; Persson, P. Organic farming increases richness of fungal taxa in the wheat phyllosphere. Mol. Ecol. 2017, 26, 3424-3436. [CrossRef]

40. Khan, N.; Martínez-Hidalgo, P.; Ice, T.A.; Maymon, M.; Humm, E.A.; Nejat, N.; Sanders, E.R.; Kaplan, D.; Hirsch, A.M. Antifungal activity of Bacillus species against Fusarium and analysis of the potential mechanisms used in biocontrol. Front. Microbiol. 2018, 9, 2363. [CrossRef]

41. Zhang, D.; Yu, S.; Yang, Y.; Zhang, J.; Zhao, D.; Pan, Y.; Fan, S.; Yang, Z.; Zhu, J. Antifungal effects of volatiles produced by Bacillus subtilis against Alternaria solani in Potato. Front. Microbiol. 2020, 11, 1196. [CrossRef]

42. Mannaa, M.; Kim, K.D. Biocontrol Activity of volatile-producing Bacillus megaterium and Pseudomonas protegens against Aspergillus and Penicillium spp. predominant in stored rice grains: Study II. Mycobiology 2018, 46, 52-63. [CrossRef]

43. Palazzini, J.M.; Alberione, E.; Torres, A.; Donat, C.; Köhl, J.; Chulze, S. Biological control of Fusarium graminearum sensu stricto, causal agent of Fusarium head blight of wheat, using formulated antagonists under field conditions in Argentina. Biol. Control 2016, 94, 56-61. [CrossRef]

44. Palazzini, J.M.; Ramirez, M.L.; Alberione, E.J.; Torres, A.M.; Chulze, S.N. Osmotic stress adaptation, compatible solutes accumulation and biocontrol efficacy of two potential biocontrol agents on Fusarium head blight in wheat. Biol. Control 2009, 51, 370-376. [CrossRef]

45. Zalila-Kolsi, I.; Ben Mahmoud, A.; Ali, H.; Sellami, S.; Nasfi, Z.; Tounsi, S.; Jamoussi, K. Antagonist effects of Bacillus spp. strains against Fusarium graminearum for protection of durum wheat (Triticum turgidum L. subsp. durum). Microbiol. Res. 2016, 192, 148-158. [CrossRef] [PubMed]

46. Crane, J.M.; Bergstrom, G.C. Spatial distribution and antifungal interactions of a Bacillus biological control agent on wheat surfaces. Biol. Control 2014, 78, 23-32. [CrossRef]

47. Shi, C.; Yan, P.; Li, J.; Wu, H.; Li, Q.; Guan, S. Biocontrol of Fusarium graminearum growth and deoxynivalenol production in wheat kernels with bacterial antagonists. Int. J. Env Res. Public Health 2014, 11, 1094-1105. [CrossRef]

48. Khan, N.I.; Schisler, D.A.; Boehm, M.J.; Slininger, P.J.; Bothast, R.J. Selection and evaluation of microorganisms for biocontrol of Fusarium head blight of wheat incited by Gibberella zeae. Plant Dis. 2001, 85, 1253-1258. [CrossRef]

49. Zhao, Y.; Selvaraj, J.N.; Xing, F.; Zhou, L.; Wang, Y.; Song, H.; Tan, X.; Sun, L.; Sangare, L.; Folly, Y.M.E.; et al. Antagonistic action of Bacillus subtilis strain SG6 on Fusarium graminearum. PLoS ONE 2014, 9, 92486. [CrossRef]

50. Siddiqui, Z.A. Biocontrol of Alternaria triticina by plant growth promoting rhizobacteria on wheat. Arch. Phytopathol. Plant Prot. 2007, 40, 301-308. [CrossRef]

51. Liu, Q.; Li, W.; Feng, Y.; Tao, C. Efficacy and safety of polymyxins for the treatment of Acinectobacter baumannii infection: A systematic review and meta-analysis. PLoS ONE 2014, 9, e98091. [CrossRef] [PubMed] 
52. Ongena, M.; Jacques, P. Bacillus lipopeptides: Versatile weapons for plant disease biocontrol. Trends Microbiol. 2008, 16, 115-125. [CrossRef] [PubMed]

53. Cochrane, S.A.; Vederas, J.C. Lipopeptides from Bacillus and Paenibacillus spp.: A Gold Mine of Antibiotic Candidates. Med. Res. Rev. 2016, 36, 4-31. [CrossRef] [PubMed]

54. Caulier, S.; Nannan, C.; Gillis, A.; Licciardi, F.; Bragard, C.; Mahillon, J. Overview of the antimicrobial compounds produced by members of the Bacillus subtilis group. Front. Microbiol. 2019, 10, 302. [CrossRef] [PubMed]

55. Kusari, S.; Hertweck, C.; Spiteller, M. Chemical ecology of endophytic fungi: Origins of secondary metabolites. Chem. Biol. 2012, 19, 792-798. [CrossRef] [PubMed]

56. Peles, F.; Sipos, P.; Kovács, S.; Gyori, Z.; Pócsi, I.; Pusztahelyi, T. Biological control and mitigation of aflatoxin contamination in commodities. Toxins 2021, 13, 104. [CrossRef] [PubMed]

57. Ianiri, G.; Idnurm, A.; Wright, S.A.I.; Durán-Patrón, R.; Mannina, L.; Ferracane, R.; Ritieni, A.; Castoria, R. Searching for genes responsible for patulin degradation in a biocontrol yeast provides insight into the basis for resistance to this mycotoxin. Appl. Env Microbiol. 2013, 79, 3101-3115. [CrossRef] [PubMed]

58. Ianiri, G.; Pinedo, C.; Fratianni, A.; Panfili, G.; Castoria, R. Patulin degradation by the biocontrol yeast Sporobolomyces sp. Is an inducible process. Toxins 2017, 9, 61. [CrossRef] 